\title{
Mutu dan Perhitungan Biaya Pembekuan Fillet Ikan Nila (Oreochromis niloticus) menggunakan Contact plate freezer Skala Laboratorium
}

\begin{abstract}
Quality and freezing cost calculation of Tilapia fillet (Oreochromis niloticus) by using contact plate freezer in laboratory scale.
\end{abstract}

\author{
I Ketut Sumandiarsa ${ }^{1}$, Arpan N. Siregar ${ }^{1}$, R. Okta Priadi ${ }^{2}$ \\ ${ }^{1}$ Laboratorium pengolahan hasil perikanan, Sekolah Tinggi Perikanan \\ 2.Jurusan Teknologi Pengolahan Hasil Perikanan, Sekolah Tinggi Perikanan \\ Email: ketut_andi@yahoo.com
}

\begin{abstract}
Abstrak
Penelitian bertujuan untuk mengetahui pengaruh pengemasan fillet ikan terhadap mutu dan biaya pembekuan. Penelitian dilaksanakan di Laboratorium Pendinginan dan Pembekuan Sekolah Tinggi Perikanan pada bulan Maret sampai Mei 2016. Metode penelitian yang digunakan adalah metode eksperimenal dengan dua perlakuan yaitu pengemasan dengan plastik dan tanpa dikemas yang kemudian dibekukan. Ikan Nila yang digunakan memiliki ukuran 200 - $250 \mathrm{~g}$ yang diperoleh dari pasar Minggu Jakarta. Parameter yang diamati adalah mutu organoleptik produk fillet beku, Angka Lempeng Total (ALT), karakteristik kimiawi proksimat (Protein, Lemak, Air dan Abu) dan biaya pembekuan. Hasil penelitian dapat disimpulkan bahwa kemasan tidak berpengaruh $(\mathrm{P}>0.05)$ terhadap karakterisktik fillet ikan Nila baik dari segi organoleptik, ALT, proksimat. Nilai organoleptik diperoleh rata-rata 8 , ALT dikemas plastik $1,9 \times 10^{4} \mathrm{kol} / \mathrm{gr}$ dan tanpa plastik $2,0 \times 10^{4} \mathrm{kol} / \mathrm{gr}$, sedangkan proksimat fillet dikemas platik dan tanpa plastik adalah air 83,7\% dan $83 \%$; abu $0,5 \%$ dan $0,5 \%$; protein $18,64 \%$ dan $18,46 \%$; lemak 3,08\% dan 3,08\%. Laju penurunan suhu fillet yang tidak menggunakan plastik lebih cepat dibandingkan dengan fillet yang menggunakan plastik dan biaya pembekuan perkilogram fillet sebesar Rp $246,57,-$.
\end{abstract}

Kata kunci:ikan Nila, proksimat, fillet, pembekuan

\begin{abstract}
The research on quality and freezing cost calculation of Tilapia fillet (Oreochromis niloticus) by using contact plate freezer in laboratory scale is aimed to define effect of using plastic as wrapping and without wrapping on its quality and also freezing cost. The research was conducting in chilling and freezing laboratory at Sekolah Tinggi Perikanan Jakarta from February until May 2016. The method used the experimental design with 2 treatments of wrapping: with plastic wrapping and without wrapping and then freezed by using CPF. The size of Tilapia was approximately about $200-250 \mathrm{~g} /$ fish which is found from Pasar Minggu Jakarta market. Observation parameters were about oOrganoleptic, Total Plate count (TPC),proximate and cost of freezing. The results of the research that the wrapping was not effect on organoleptic quality of Tilapia fillet. TPC and proximate characteristics also. Quality related to organoleptic was in average of 8 . Based on proximate result of with and without plastic the water content was $83,7 \%$ and $83 \%$, ash content was about $0,5 \%$ and $0,5 \%$, protein content around $18,64 \%$ and $18,46 \%$, and lipid content was approximately $3,08 \%$ and 3,08\%. TPC result showed that the product was both in good condition $\left(1,9 \times 10^{4} \mathrm{col} / \mathrm{gr}\right.$ and $2,0 \times 10^{4} \mathrm{col} / \mathrm{gr}$ respectively). The rate of temperature decline was different between plastic and without plastic (without plastic was faster). It is found also that the cost of freezing was Rp 246,57,-/ kg of Tilapia fillet.
\end{abstract}

Keywords: Tilapia, proximate, fillet, freezing. 
I Ketut Sumandiarsa:Mutu dan Perhitungan Biaya Pembekuan Fillet Ikan Nila (Oreochromis niloticus) menggunakan Contact plate freezerSkala Laboratorium.

\section{Pendahuluan}

Indonesia memiliki lahan perikanan air tawar yang sangat besar. Tentu saja, hal ini merupakan potensi yang besar dalam pengembangan budidaya perikanan untuk mendukung upaya pemulihan dan pembangunan perekonomian nasional. Pemanfaatan potensi tersebut akan dapat mendorong dan menghidupkan kegiatan produksi berbasis ekonomi rakyat, mempercepat pembangunan ekonomi masyarakat di pedesaan serta berpeluang untuk meningkatkan devisa negara (Sucipto dan Prihartono, 2005). Salah satu pasar potensial ekspor ikan NIla adalah Amerika Serikat dengan total volume 230.738 ton atau senilai 1.110 juta USD pada tahun 2013. Pada triwulan I tahun 2015 tercatat bahwa ekspor ikan Nila Indonesia ke Amerika Serikat telah mencapai angka 71.742 ton atau senilai 328 juta USD. (Nasa, 2015).

Pembekuan adalah proses transfer panas yang tidak tetap selama proses pembekuan sehingga sangat penting untuk melakukan perhitungan baik secara konvesional ataupun modern (contohnya dalam penggunaan persamaan Plank) (Hall, 2011). Pembekuan dengan menggunakan Contact plate freezer utamanya untuk membekukan produk yang berbentuk fillet, blok dan dikemas dengan kombinasi suhu dan tekanan dari plat pembeku sehingga menghasilkan waktu pembekuan yang cepat (quick freezing) (Granata, et.al, 2012). Teknologi terbaru yang telah diperkenalkan secara luas seperti pembekuan tumbukan (Impingement freezing) yang dapat mencapai kecepatan pembekuan setara dengan Nitrogen cair karena dilengkapi dengan hembusan udara dingin sangat cepat dari atas dan bawah secara langsung (Boziaris, 2014). Menurut penelitian Mazrouh (2015) bahwa karakteristik kimiawi (proksimat) ikan beku secara signifikan mengalami penurunan akibat pembekuan khususnya penyimpanan beku setelah 21 hari. Sedangkan menurut Ozbay (2006), denaturasi protein akibat pembekuan atau penyimpanan beku mulai terjadi setelah 6 minggu.

Melihat potensi pasar ikan Nila yang terus meningkat setiap tahunnya, maka perlu mengembangakan metode pembekuan yang tepat dan menghitung biaya pembekuan perkilogram fillet yang tepat dalam rangka mengoptimalisasikan alat pembeku secara efektif dan efisien.

\section{Tujuan}

Penelitian ini bertujuan untuk mengetahui pengaruh perlakuan pengemasan (dengan plastik dan tidak menggunakan plastik) pada saat pembekuan terhadap mutu fillet ikan nila beku dengan parameter uji organoleptik, proksimat dan ALT. Mengetahui laju penurunan suhu pada dua model pengemas yang dibekukan dengan menggunakan CPF dan menghitung biaya pembekuan perkilogram fillet ikan Nila.

\section{Bahan dan Metode}

\section{Bahan}

Bahan yang digunakan dalam penelitian ini adalah ikan Nila (Oreochromis niloticus) segar dengan ukuran antara 200 s.d. 250 g per ekor yang didapatkan dari pasar Pasar Minggu, es, larutan $\mathrm{HCl} 0,1 \mathrm{M} \mathrm{pH} \mathrm{7,} \mathrm{aquadest,} \mathrm{larutan} \mathrm{n-}$ Heksana $\left(\mathrm{C}_{6} \mathrm{H}_{14}\right), \mathrm{NaOH} 30 \%$, Asam Borat 2 $\%, \mathrm{HCl} 0,01 \mathrm{~N}$. Alat yang digunakan antara lain Contact plate freezer, pisau fillet, Tanur, listrik, Desikator, Soklet, Oven, Labu kjeldahl, Destilator, dan Destructor.

\section{Metode}

Penelitian ini dilakukan dengan melakukan pegujian mutu bahan baku, kemudian dilakukan pemfilletan yang selanjutnya dibekukan. Uji proksimat meliputi uji kadar air (termogravimetri), uji kadar abu (furnace), uji kadar protein (metode Kjeldahl) dan uji lemak (metode ekstraksi) di laboratorium Kimia STP dan ALT pada sampel fillet beku setelah 1 hari pembekuan. Penggunaan plastik dan tanpa plastik dilakukan untuk menutup fillet pada saat pembekuan berlangsung. Penurunan suhu produk dan mesin pembeku dicek setiap menit dan setelah beku kemudian diuji Proksimat. Hasil pengujian kemudian dianalisa statistik terkait dengan pengaruh plastic terhadap mutu produk. Perhitungan biaya pembekuan dilakukan dengan memperhitungkan kapasitas Contact Plate Freezer (CPF), panas spesifik produk yaitu panas awal produk sebelum dibekukan, panas laten produk dan panas spesifik dibawah beku, berat produk yang di bekukan dan suhu akhir dari alat pembeku tersebut serta beban listrik sesuai dengan 
ketetapan kepmen ESDM tentang tarif listrik dan harga ikan sebagai objek pembekuan,

\section{Hasil dan Pembahasan}

\section{Mutu Sensosi organoleptik}

Hasil uji mutu pada produk akhir fillet nila beku yang menggunakan dan tanpa menggunakan plastik di peroleh rata - rata organoleptik 8 dari 12 sampel dan di uji setelah pembekuan berlangsung. Nilai organoleptik cukup tinggi disebabkan karena proses pembekuan berlansung dalam waktu \pm 2 jam dimana pembekuan pada produk merata namun lapisan es cukup tebal sedangkan seluruh permukaan terlapisi es dengan baikserta hanya sedikit mengalami perubahan warna pada permukaan produk. Perubahan warna pada daging ikan beku dapat terjadi akibat proses pembekuan dan penyimpanan beku yang berlangsung lama serta biasanya menjadi salah satu indikator terjadinya dehidrasi pada produk (Ilyas, 1993). Karakteristik sensori produk juga dipengaruhi oleh factor intrinsick seperti perubahan komposisi kimia dan fisik akibat dari proses enzymatic sedangkan factor ekstrinsik lebih dipengaruhi oleh aktivitas mikrobilogi (Alasalvas, et.al, 2011). Perubahan tekstur sangat berkaitan dengan denaturasi protein yang mengakibatkan penurunan kelarutannya sehingga menjadi awal terjadinya kekeringan dan produk menjadi keras/alot (Hall, 2011). Pembentukan kristal es pada produk juga mempengaruhi sensori produk beku dimana semakin cepat pembekuan maka akan menghasilkan kristal es yang lebih halus sehingga penggunaan alat pembeku yang tepat akan menghasilkan produk dengan mutu yang baik (Boziaris, 2014).

Produk beku yang mengalami penurunan mutu dapat dirasakan pada saat ikan tersebut di masak dimana ikan tersebut keras/alot, berserat, kenyal dan seperti karet akibat dari hilangnya daya penahan air pada daging ikan (Kramer, et.al dalam Granata et.al, 2012).Berdasarkan penelitian Mazrouh (2015), mutu ikan beku selama penyimpanan beku memperlihatkan penurunan dari segi rasa yang signifikan seiring waktu penyimpanan. Oleh kKarena itu, organoleptik fillet beku belum mengalami penurunan karena proses degradasi belum berjalan. Menurut penelitian yang dipublikasi Journal of Food Processing and Preservation (2015) bahwa penyimpanan beku selama 4 bulan mengakibatkan penurunan atribut sensori seperti kenampakan, warna, rasa, tekstur dan penerimaan secara menyeluruh lainnya. Dengan demikian, semakin lama disimpan maka produk akan semakin jauh dari standar mutu sensori.

\section{Karakteristik Kimia (proksimat)}

Berikut adalah hasil pengujian pada 2 perlakuan pembekuan fillet ikan Nila. Berdasarkan uji statistik didapatkan bahwa tidak ada pengaruh nyata perbedaan perlakuan pengemasan fillet terhadap mutu proksimat produk fillet ikan Nila beku $(\mathrm{P}>0,05)$.

Tabel 1. Hasil pengujian kadar proksimat.

Table 1. Result proximate test

\begin{tabular}{lllll}
\hline Perlakuan & Air & Abu & Protein & Lemak \\
\hline Kemas plastik & $83,7^{\mathrm{a}} \pm 0,47$ & $0,5^{\mathrm{a}} \pm 0,02$ & $18,64^{\mathrm{a}} \pm 0,39$ & $3,07^{\mathrm{a}} \pm 0,02$ \\
Tanpa dikemas & $83,0^{\mathrm{a}} \pm 0,47$ & $0,5^{\mathrm{a}} \pm 0,02$ & $18,46^{\mathrm{a}} \pm 0,39$ & $3,08^{\mathrm{a}} \pm 0,02$ \\
\hline
\end{tabular}

Berdasarkan tabel 1 diatas, kadar air pada kedua perlakuan tidak berbeda nyata artinya tidak ada pengaruh nyata dari perlakuan pengemasan. Pada proses pembekuan fillet ikan Nila yang tidak menggunakan plastik kontak langsung dengan Contact Plate Freezer (CPF) sehingga air atau panas yang ada pada daging filletdihilangkan lebih cepat dibandingkan dengan fillet menggunakan plastik. Produk yang tidak dilindungi dengan kemasan akan lebih pendek waktu pembekuannya, tetapi selama pembekuan berlangsung akan menghadapi masalah pengeringan dan oksidasi.

Pengeringan terjadi karena adanya penguapan air dari permukaan ikan yang disebabkan oleh pembekuan. Akibatnya, uap air ikan menguap ke permukaan sehingga ikan mengalami pengeringan (dehidrasi) (Ilyas, 1993). Kadar air yang diperoleh masih menunjukan bahwa kadar air ikan Nila cukup tinggi dan masih terbilang memenuhi standar kadar air pada ikan. Menurut (Afrianto dan Liviawaty, 1989) ikan memiliki kandungan 
I Ketut Sumandiarsa:Mutu dan Perhitungan Biaya Pembekuan Fillet Ikan Nila (Oreochromis niloticus) menggunakan Contact plate freezerSkala Laboratorium.

kadar air 60,0 - 84,0\%. Menurut Jessen, et.al (2014) dalam Boziaris (2014) bahwa jumlah air pada produk beku tidak berubah dalam jumlah yang signifikan namun hanya berubah bentuk dari cair menjadi kristal es. Perubahan bentuk ini sangat dipengaruhi oleh kecepatan pembekuan (fast - ultra fast freezing).

Pengaruh pengemasan terhadap kadar abu tidak menunjukkan pengaruh nyata $(\mathrm{P}>0,005)$. Menurut Afrianto dan Liviawaty (1989) kandungan komposisi kimia pada ikan terdiri dari 60,0 - 84,0\% kadar air, 18,0 - 30,0\% kadar protein, $0,1-2,2 \%$ lemak, $0,0-1,0$ karbohidrat dan sisanya vitamin dan mineral. Komposisi protein dan lemak pada uji proksimat produk beku umumnya lebih berpengaruh dan relatif populer karena memiliki dampak yang besar seperti pada pembentukan oksidasi dan denatirasi pada saat penyimpanan beku (Kramer, et.al dalam Granata et.al, 2012).

Hasil yang diperoleh pada pengujian protein pada fillet ikan Nila yang menggunakan plastik dan tidak menggunakan plastik yaitu $18,64 \%$ pada fillet yang menggunakan plastik dan $18,46 \%$ yang tidak menggunakan plastik. Tidak ada perbedaan antara penggunaan plastik dan tidak menggunakan plastik terhadap kadungan protein pada fillet ikan Nila. Hail ini disebabkan oleh penurunan suhu pembekuan mencapai $-18^{\circ} \mathrm{C}$ adalah tingkat suhu rendah optimal pada ikan dimana kegiatan denaturasi proteinnya rendah. Suhu ikan semakin diturunkan maka semakin berkurang laju denaturasi. Menurut Venon (2015) dalam Kim (2015) bahwa denaturasi protein terjadi pada tahap penyimpanan beku yang terkait dengan suhu penyimpanan dan kondisi pelapisan seperti glazing atau protein coating.

Protein coating menghasilkan keuntungan terbesar dalam hal mengontrol penurunan mutu akibat penyimpanan beku. Kondisi protein dipengaruhi juga oleh terganggunya struktur air pada daerah hidropobik protein dan pecahnya interaksi air hidropilik-hidropobik. Selain itu, degradasi protein juga dapat dilihat dari kondisi daging ikan yang keras dan kering yang menjadi loss paling besar pada produk beku terutama pada ikan berlemak rendah (Kramer, et.al dalam Granata et.al, 2012). Komposisi protein ikan beku akan menurun secara signifikan pada saat mengalami pembekuan ulang setelah di thawing dibandingkan dengan fillet ikan yang masih segar (Zakhariya, et.al, 2013) sedangkan menurut Ozbay (2006), protein mengalami denaturasi sangat cepat akibat penyimpanan beku dengan suhu hanya $-5^{0} \mathrm{C}$ dalam waktu 6 minggu. Menurut penelitian Fukuma, et.al (2012), terjadinya denaturasi protein pada saat pembekuan sangat dipengaruhi oleh kecepatan pembekuan karena pembekuan super cepat dapat menghasilkan cristal es halus sedangkan pembekuan lambat (mesin pembeku konvensional) akan membentuk drip yang mengakibatkan denaturasi protein.

Kadar lemak produk sangat dipengaruhi oleh jenis ikan. Semakin tinggi kadsar lemak maka semakin tinggi kemungkinan terjadinya degradasi mutu seperti oksidasi lemak.

Hasil yang diperoleh pada pengujian kadar lemak pada fillet ikan Nila yaitu 3,08 \% hasil ini menunjukkan bahwa tidak ada perbedaan kandungan lemak yang dihasilkan pada pengujian produk akhir $(\mathrm{P}>0,05)$. Proses pembekuan yang dilakukan menggunakan perlakukan yang berbeda tidak mempengaruhi kandungan lemak pada fillet ikan Nila. Menurut Ilyas, 1993, pembekuan harus mampu mempertahankan mutu biologis, organoleptik, dan fisik. Perubahan organoleptik (rupa, warna, odor, citaras, dan tekstur) dan biokimia (denaturasi protein, oksidasi lemak, vitamin dan pigmen) serta perubahan kimiawi yang lainnya haruslah minimum dan mampu menonaktifkan kegiatan bakteri hingga tidak dapat menurunkan mutu ikan. Kandungan lemak pada produk akan mempengaruhi daya awet akibat dari terbentuknya oksidasi dan pembentukan aroma tengik (Kramer, et.al dalam Granata et.al, 2012). Pada ikan hidup, lemak dapat dipertahankan secara stabil karena pengaruh keseimbangan antioksidan dan prooksidan. Lemak terdegradasi seiring dengan denaturasi protein dimana terjadi peningkatan atau aktivasi pro-oksidan, kehilangan atau inaktivasi antioksidan, aktivitas enzim dan terpecahnya membran sel yang mengakibatkan oksidasi lemak (Jessen et.al, 2014 dalam Boziaris, 2014). Ketengikan memiliki asosiasi yang sangat erat dengan suhu penyimpanan beku dimana daging ikan beku disimpan pada suhu $-5^{\circ} \mathrm{C}$ mengalami ketengikan yang secara signifikan lebih cepat dari pada yang disimpan pada suhu $-20^{\circ} \mathrm{C}$ (Ozbay, 2005) sedangkan menurut Choubert, et. all (2011), kualitas lemak sangat dipengaruhi oleh lama penyimpanan beku dimana ikan rainbow Trout 
fillet yang disimpan beku $\left(-18^{0} \mathrm{C}\right)$ mengalami ketengikan pada penyimpanan ke-6 bulan.

\section{Hasil pengujian mikrobiologi}

Dari hasil pengujian ALT diatas produk akhir fillet ikan Nila yang menggunakan plastik dan tanpa menggunakan plastik diperoleh Nilai rata - rata $1,9 \times 10^{4} \mathrm{kol} /$ grdan $2,0 \times 10^{4} \mathrm{kol} / \mathrm{gr}$. Hasil ini menunjukan bahwa produk akhir fillet ikan Nila masih memenuhi persyaratan SNI 01-2332.3-2006 tentang penentuan angka lempeng total (ALT) produk perikanan. Selain itu, penggunaan bahan baku ikan Nila yang masih hidup juga mempengaruhi jumlah mikroorganisme pada daging fillet ikan Nila. Menurut Afrianto dan Liviawaty (1989), ikan hidup memiliki kemampuan untuk mengatasi aktivitas mikroorganisme sehingga tidak terlihat selama ikan hidup.

Proses pembekuan ikan juga mengurangi jumlah sampai dengan $90 \%$ atau satu siklus logaritmetrik. Artinya jumlah awal bakteri per gram ikan sekitar puluhan ribu, maka langsung setelah pembekuan hanya tinggal ribuan saja (Ilyas, 1993). Menurut Kramer (2012) dalam Granata (2012) bahwa total bakteri pada produk sesaat setelah pembekuan adalah 1.500 kol/gram artinya ALT produk cukup tinggi yang mungkin diakibatkan oleh kontaminasi pada saat preparasi sampel. Pembekuan menghambat aktivitas mikroba melalui penurunan $a_{w}$ tetapi tidak memiliki efek membunuh semua bakteri dengan beberapa bakteri gram negative dan spora menjadi resistan. Bakteri yang bertahan akan muncul pada saat proses thawing (Hall, 2011). Berdasarkan hasil penelitian Zakhariya, et.al (2013) bahwa ALT suatu produk beku akan mengalami peningkatan jika terjadi proses pembekuan ulang dimana fillet ikan Barramundi mengalami peningkatan nilai ALT sejalan dengan pembekuan ulang ke-1 hingga ke-3 secara signifikan. Selain itu, dari segi keamanan dan mutu secara mikrobilogi tidak dapat terjamin seperti tingkat kontaminasi tinggi yang terjadi pada area pengolahan. Dinyatakan bahwa kontaminasi Escherichia coli, Staphylococcus aureus dan Vibrio cholera paling banyak ditemukan pada tangan pekerja dan khususnya di area pengemasan (Thi, et. all, 2014).

\section{Laju penurunan suhu}

Kecepatan penurunan suhu pembekuan pada produk diukur setiap 8 menit hingga mencapai suhu $-18^{\circ} \mathrm{C}$ padaproduk yang dibekukan yang dikemas dengan menggunakan plastik dan tidak menggunakan plastik.

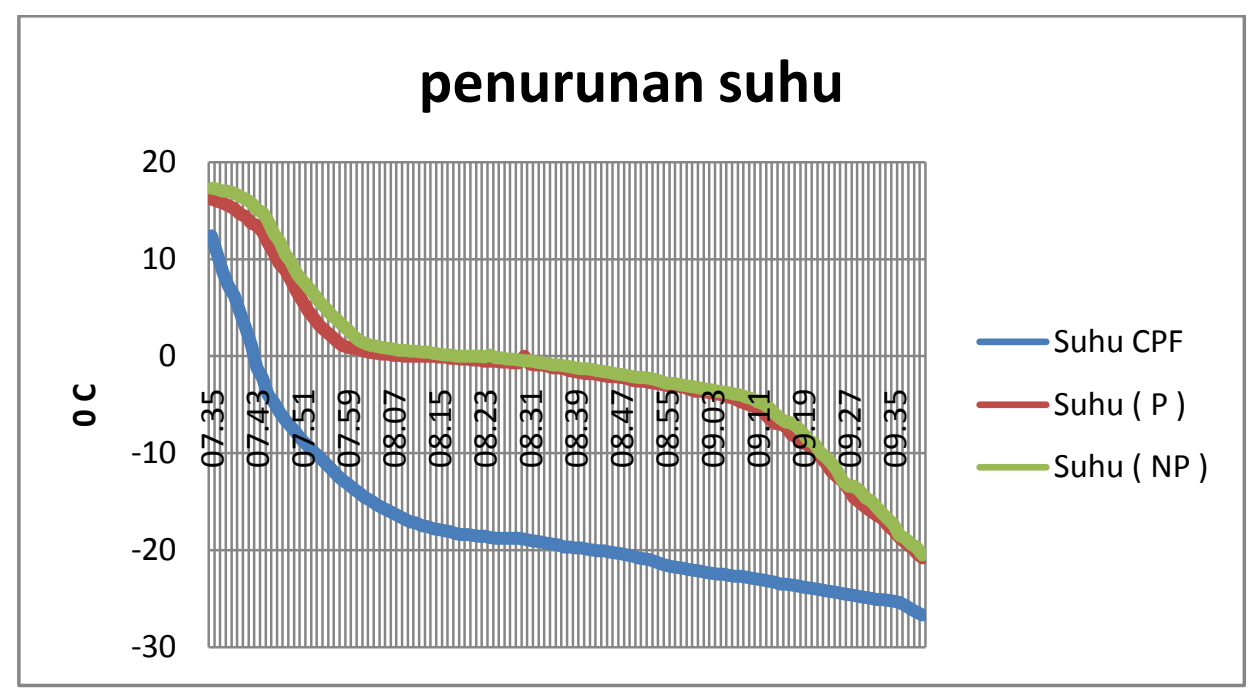

Gambar 1. Penurunan Suhu Pada Saat Pembekuan

Figure 1. Temperature Decrease during Process

Berdasarkan Gambar 1 tersebut dapat dilihat bahwa penurunan suhu antara produk yang dikemas plastic dan tidak dikemas memiliki laju yang sedikit berbeda, hal ini dikarenakan plastik dapat menghambat penarikan suhu pada fillet sehingga penurunan suhu ikan menjadi sedikit lambat dibandingkan dengan tidak menggunakan plastik. Menurut (Ilyas, 1993) produk yang tidak dilindungi dengan kemasan akan lebih pendek waktu 
I Ketut Sumandiarsa:Mutu dan Perhitungan Biaya Pembekuan Fillet Ikan Nila (Oreochromis niloticus) menggunakan Contact plate freezerSkala Laboratorium.

pembeakuannya, tetapi selama pembekuan berlangsung akan menghadapi masalah pengeringan dan oksidasi. Oleh karena itu produk perlu dilindungi dengan bahan dan cara pengemasan yang sangat kecil nilai insulasinya. Adapun titik beku yangd

\section{Perhitungan Biaya Pembekuan}

Perhitungan biaya pembekuan disajikan sebagai berikut : didapatkan berdasarkan grafik tersebut adalah antara $-1{ }^{0} \mathrm{C}$ s.d. $-4.5^{\circ} \mathrm{C}$. Hal ini relatif sama dengan pembekuan yellowtail dan sSalmon yang memiliki titik beku antara -1.3 and $-2.5^{\circ} \mathrm{C}$ (Fukuma, et.all, 2012)

$\mathrm{Cp}$ atas $\quad=0,0335 \mathrm{x} \mathrm{a}+0,84 \mathrm{kj} / \mathrm{kg}^{\circ} \mathrm{C}$

Laten Heat $=334 \mathrm{x} \mathrm{a}$

Cp bawah $\quad=0,0126 \times \mathrm{a}+0,84 \mathrm{kj} / \mathrm{kg}^{\circ} \mathrm{C}$

Ket : a = kadar air produk $(\%)$

$\mathrm{Cp}$ atas $=$ kalor spesifik di atas titik beku

$\mathrm{Cp}$ bawah= kalor spesifik di bawah titik beku

$$
\begin{aligned}
\mathrm{Cp} \text { atas } & =0,0335 \times 0,83+0,84 \mathrm{kj} / \mathrm{kg}^{\circ} \mathrm{C} \\
& =0,868 \text { kilojoule } \\
\text { Laten Heat } & =334 \times 0,83 \\
& =277,22 \text { kilojoule } \\
\text { Cp bawah } & =0,0126 \times 0,83+0,84 \mathrm{kj} / \mathrm{kg}^{\circ} \mathrm{C} \\
& =0,850 \text { kilojoule }
\end{aligned}
$$

Tabel 2. Data Perhitungan Pembekuan

Table 2. Frozen Calculation Data

\begin{tabular}{ccc}
\hline Produk & Uraian & Hasil \\
\hline Fillet ikan Nila & Berart produk $(\mathrm{kg})$ & $200 \mathrm{~kg}$ \\
& Suhu awal $\left({ }^{\circ} \mathrm{C}\right)$ & $15^{\circ} \mathrm{C}$ \\
& Titik beku & $-2,2^{\circ} \mathrm{C}$ \\
& Suhu akhir CPF & $-41^{\circ} \mathrm{C}$ \\
\hline
\end{tabular}

$$
\begin{aligned}
& \text { Q1 = 2985,92 kilojoule } \\
& \text { Q2 }=55444 \text { kilojoule } \\
& \mathrm{Q} 3=6596 \text { kilojoule } \\
& \text { Qtotal }=\mathrm{Q} 1+\mathrm{Q} 2+\mathrm{Q} 3 \\
& =65025,92 \text { kilojoule }
\end{aligned}
$$

1. Q total (kilojoule) dikalikan dengan $0.000278(1 \mathrm{~kJ}=0.000278 \mathrm{kWh})$ ini berdasarkan ketetapan mesin konversi energi (unit converter).

2. kWh dikalikan dengan lama waktu pembekuan kemudian dikali dengan $\mathrm{Rp}$ 1.364,- (ketetapan kepmen ESDM), hasilnya adalah harga pembekuan per hari.
3. Harga pembekuan per hari dibagi dengan berat produk yang dihasilkan per hari, maka hasilnya adalah pembekuan per jam. 
Perhitungan Biaya Perkilogram fillet ikan Nila:

$\mathrm{Q}$ total $=65025,92 \times 0,000278 \mathrm{kWh}$

$=18,07720576 \mathrm{kWh} \times 2$ jam

$=36,15441152 \mathrm{kWh}$ x Rp 1.364,-

(tarif dasar listrik)

$=49.315,-$ rupiah per $2 \mathrm{jam}$

Maka biaya pembekuan fillet ikan Nila per proses pembekuan sebesar Rp 49.315,-. Maka biaya pembekuan per proses pembekuan dibagi dengan berat produk yang dihasilkan.

Biaya per proses $=\operatorname{Rp} 49.315,-$

$$
=246,57 / \mathrm{kg}
$$$$
200 \mathrm{~kg} \text { per } 2 \text { jam }
$$

Maka hasil perhitungan biaya pembekuan perkilogram fillet ikan Nila sebesar Rp 246,57,-dalam setiap prosespembekuan.

\section{Simpulan}

Berdasarkan uraian di atas penulis dapat menarik kesimpulan sebagai berikut :

1. Pengemasan fillet ikan Nila saat dibekukan tidak mempengaruhi karakteristik kimiawi, sensori, dan ALT produk akhir.

2. Suhu fillet ikan tanpa dikemas plastik lebih cepat menurun jika dibandingkan dengan dikemas plastik. Hasil perhitungan biaya perkilogram fillet ikan Nila yang dibekukan dengan berat produk 200 kgsebesar $\mathrm{Rp}$ $246,57,-/ \mathrm{kg}$ untuk setiap proses pembekuan.

\section{Saran}

Diperlukan penelitian lebih lanjut mengenai analisa usaha pembekuan fillet ikan nila skala usaha sehingga dapat ditentukan jumlah produksi minimum agar usaha layak dijalankan secara bisnis.

\section{Daftar Pustaka}

Afrianto. E dan Liviawaty. E. 1989. Pengawetan dan Pengolahan Ikan. Kanisius. Yogyakarta.

Alasalvar, C., Shahidi, F., Miyashita, K., dan Wanasundara, U. 2011. Handbook of Seafood Quality, Safety and Health Application. Wiley-Blackwell. USA (1 542).

Boziaris, I.S,. 2014. Seafood Processing: Technology, Quality and Safety. WileyBlackwell. USA (1 - 488).
(BSN)Badan Standarisasi Nasional 2006. SNI 01-4103.1-2006. Fillet nila (Tilapia sp) Bagian 1: Spesifikasai

(BSN)Badan Standarisasi Nasional 2006. SNI 01-2729.2-2006. Ikan Segar Bagian 2: Persyaratan Bahan Baku

(BSN)Badan Standarisasi Nasional 2006. SNI 01-4103.3-2006. Fillet nila (Tilapia sp) Bagian 3: Penannganan dan Pengolahan

(BSN)Badan Standarisasi Nasional 2006. SNI 01-2332.3-2006. Cara Uji MikrobiologiBagian 3: Penentuan Angka Lempeng Total (ALT) Pada Produk Perikanan.

Fukuma. Y, Yamane. A, Itoh. T, Tsukamasa. Y, dan Ando. M. 2012. Application of supercooling to long-term storage of fish meat. Food Science and Technology Journal: The Japanese Society of Fisheries Science.

Granata, L.A, Flick, G. J, dan Martin, R. E, 2012.The Seafood Industry: Species, Products, Processing, and Safety. WileyBlackwell. USA (1 - 468).

Hall, G.M., 2011. Fish Processing: Sustainable and New Opportunities. WileyBlackwell. USA (1 - 296).

Handoko. 1981. Teknik Lemari Es. PT. Ictiar Baru, Cetakan II, Jakarta

Ilyas S. 1993. Teknologi Refrigerasi Hasil Perikanan. Jilid II. CV Paripurna. Jakarta.

Journal of Food Processing and Preservation. 2015. Biochemical and Sensory Acceptability Changes of Fish Cutlet Prepared from Filleting Waste of Reef Cod (Epinephelus chlorostigma) during Frozen Storage. Journal of Food Processing and Preservation, 2015;39(4):369-375

Kim, Se-Kwon, 2015. Seafood Science: Advances in Chemistry, Technology and Application. CRC Press. Busan, Korea Selatan.

Mazrouh. M.M. 2015. Effects of freezing storage on the biochemical composition in muscles of Saurida undosquamis (Richardson, 1848) comparing with imported frozen. International Journal of 
I Ketut Sumandiarsa:Mutu dan Perhitungan Biaya Pembekuan Fillet Ikan Nila (Oreochromis niloticus) menggunakan Contact plate freezerSkala Laboratorium.

Fisheries and Aquatic Studies 2015; 3(2): 295-299

Nasa S.D. 2015. Potensi Pasar Ikan Air Tawar.

Fromhttp://www.viternaplus.com/2015 111/potensi-pasar-ikan-air-tawar.html, 19 Januari 2016

OZBAY. G, SPENCER. K, and GILL. T.A. 2006. Investigation Of Protein Denaturation And Pigment Fading In Farmed Steelhead (Onchorhychus Mykiss) Fillets During Frozen Storage. Journal of Food Processing and Preservation 30 (2006) 208-230.

Sucipto. A dan Prihartono. 2005. Pembesaran Nila Merah Bangkok. Penebar Swadaya. Jakarta.

Thi, A.N.T, Jacxsens. L, Noseda. B, Samapundo,S, Nguyen, B.L. Heyndrickx, M. and Devlieghere, F. 2014. Evaluation of the microbiological safety and quality of Vietnamese Pangasius hypophthalmus during processing by a microbial assessment scheme in combination with a selfassessment questionnaire. Food Science and Technology Journal: The Japanese Society of Fisheries Science.

Winarno. F. G dan Surono. 2004. Cara Pengolahan Yang Baik dan benar. Bogor

Zakhariya. S.Y, FOTEDAR. $\mathrm{R}$ and PRANGNELL.D. 2013. Effects Of Refreezing On Microbiological And Physiochemical Properties Of Barramundi (Lates Calcarifer, Bloch) Fillets. Journal of Food Processing and Preservatio 